\title{
Desain Truck Carrier Ro-Ro untuk Rute Pelayaran Lampung-Bali
}

\author{
Andre Perdana Setiawan dan Wasis Dwi Aryawan \\ Departemen Teknik Perkapalan, Fakultas Teknologi Kelautan, Institut Teknologi Sepuluh Nopember (ITS) \\ e-mail:wasis@na.its.ac.id
}

\begin{abstract}
Abstrak-Kemacetan yang tinggi di jalur darat, terutama di Jalan Pantura membuat Menteri Perhubungan berencana untuk membangun Truck Carrier Ro-Ro sebagai alat angkut truk. Studi ini bermaksud memberikan solusi untuk mengganti akses transportasi truk dari darat menjadi akses transportasi laut. Studi ini bertujuan untuk membangun Truck Carrier Ro-Ro untuk Rute Pelayaran Lampung-Bali. Rute Truck Carrier Ro-Ro ini dimulai dari Pelabuhan Panjang (Lampung) -Pelabuhan Tanjung Priok (Jakarta) -Pelabuhan Tanjung Emas (Semarang) - Pelabuhan Tanjung Perak (Surabaya) -Pelabuhan Benoa (Bali).Penentuan payload dilakukan berdasarkan Studi yang sudah ada, yang kemudian dijadikan sebagai acuan dasar dalam melakukan parametric design. Jumlah payload tersebut digunakan untuk pembuatan layout awal dengan beberapa variasi yang akan digunakan dalam menentukan jumlah payload yang akan digunakan. Setelah itu didapatkan ukuran utama dari layout yang telah di desain. Setelah itu dilakukan perhitungan teknis berupa berat, trim, freeboard, dan stabilitas. Ukuran utama yang di dapatkan adalah $L p p=145 \mathrm{~m} ; B=30 \mathrm{~m} ; \mathrm{H}=11$ $\mathrm{m} ; \mathrm{T}=6 \mathrm{~m}$. Tinggi freeboard minimum sebesar $916 \mathrm{~mm}$, dan kondisi stabilitas Truck Carrier Ro-Ro memenuhi kriteria Intact Stability (IS) Code Reg. III/3.1. Analisis ekonomis yang dilakukan adalah memperhitungkan biaya investasi, biaya operasional, dan harga tiket tiap rute pelayaran.
\end{abstract}

Kata Kunci-Bali, Lampung, Truck Carrier Ro-Ro, Truk.

\section{PENDAHULUAN}

$\mathrm{I}$ NDONESIA sebagai salah satu Negara Maritim terbesar di dunia dengan jumlah pulau sekitar 17.500 dan memiliki garis pantai terpanjang kedua di dunia, dimana 2/3 luas wilayah Indonesia merupakan wilayah lautan. Oleh karena itu, sudah seharusnya Pemerintah segera memanfaatkan kondisi geografis yang sangat strategis ini untuk menunjang sarana transportasi di Laut. Pulau Jawa merupakan pusat aktivitas ekonomi di Indinesia, dapat dilihat dari jumlah kepadatan penduduk di Pulau Jawa yang sangat tinggi sehingga dapat diketahui pemasokan komoditas barang kebutuhan ke Pulau Jawa sangatlah besar. Namun hingga saat ini truk di Indonesia yang merupakan salah satu penunjang sarana transportasi barang lebih memilih akses dari darat, dimana jalur darat dianggap lebih efektif dan direct. Semisal truk dari Pulau Sumatera hendak menuju ke Pulau Jawa ataupun menuju ke Bali lebih memilih jalur darat daripada jalur laut, akibatnya terjadi penumpukan kendaraan jumlah yang tinggi terutama di Jalur Pantura yang merupakan jalur utama transportasi barang di Pulau Jawa. Diketahui juga bahwa jumlah kendaraan yang melewati Jalur Pantura di perkirakan 45.000 unit per hari [1]. Melihat dari jumlah tersebut dapat di pastikan terjadi penumpukan kendaraan dengan jumlah yang besar yang akan menyebabkan kemacetan yang tinggi sehingga tidak tepatnya estimasi waktu yang sudah di tetapkan. Tidak hanya itu, efek yang ditimbulkan juga berupa usia jalan yang tidak lama (cepat rusak) dan rawan terjadi kecelakaan. Menyikapi permasalahan di atas, Menteri Perhubungan berencana untuk membangun Kapal roll-on roll-off sebagai alat angkut truk ekspedisi. Dimana pembangunan kapal ini bertujuan untuk menggangkut truk antarpulau dengan mengganti akses darat menjadi akses laut, sehingga bertujuan untuk mencegah terjadinya kepadatan di jalan raya, terutama di Jalan Pantura. Program ini juga mendukung program "Tol Laut" Pak Joko Widodo untuk memajukan sektor maritim Indonesia. Berdasarkan rencana Menteri Perhubungan, Truck Carrier Ro$R o$ ini nantinya akan di operasikan untuk Pelayaran Lampung menuju Ke Bali [2]. Sehingga dalam Studi ini, Penulis akan mendesain Truck Carrier Ro-Ro yang akan beroperasi untuk rute pelayaran Lampung - Bali.

\section{TINJAUN PUSTAKA}

Kapal Roll-on/Roll-off adalah Kapal yang bisa memuat kendaraan yang berjalan masuk dengan penggeraknya sendiri dan bisa keluar sendiri juga. Pada umumnya kapal ini berfungsi untuk menggangkut kendaaran, seperti sepeda motor, mobil,truk, dan trailer. Kapal ini biasanya dilengkapi dengan Pintu Rampa (ramp door) yang dihubungkan dengan moveble bridge (dermaga apung) atau dermaga. Jenis Kapal Ro-Ro meliputi Kapal penyebrangan/ferry, kapal penggangkut kendaraan, kapal penumpang, kapal barang, kapal pesiar . Kelebihan Kapal Ro-Ro adalah muatan dapat masuk ke kapal dengan moda,sehingga muatan tidak perlu ditumpuk di lapangan penumpang terlebih dahulu (lebih cepat dalam proses loading/unloading). Pintu rampa (ramp door) pada kapal di bagi menjadi 2 yaitu, quarter ramp dan stern ramp [3]. Namun pada kapal ini bagian stern ramp menggunakan jenis bow door. Bow door yang digunakan adalah jenis side sliding bow door.

Truk adalah sebuah kendaraan bermotor untuk mengangkut kendaraan bermotor untuk mengangkut barang, disebut juga sebagai mobil barang. Dalam bentuk yang kecil mobil barang di sebut pick-up, sedangkan bentuk lebih besar dengan 3 sumbu, 1 di depan, dan tandem di belakang disebut sebagai truk tronton, sedangkan yang digunakan untuk angkutan peti kemas dalam bentuk tempelan disebut sebagai truk trailer [4]. 

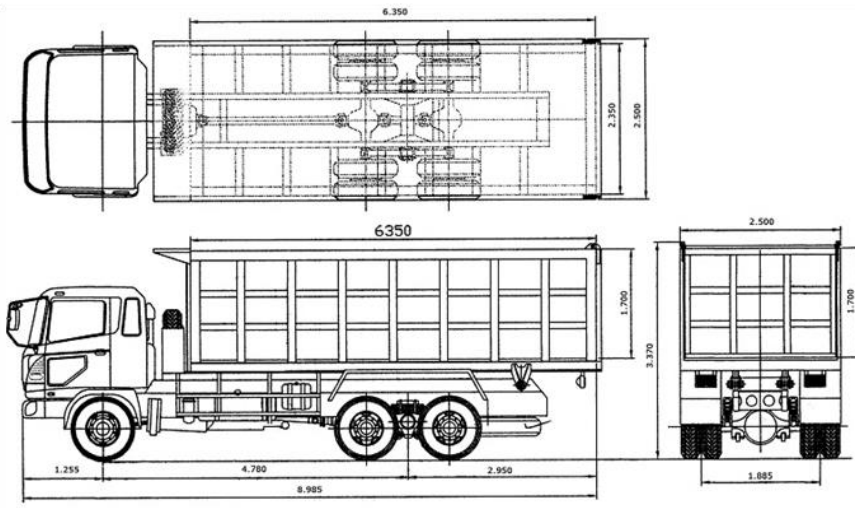

Gambar 1. Spesifikasi Truk

Berdasarkan rencana Menteri Perhubungan, Truck Carrier Ro-Ro yang akan di bangun ini akan berlayar dari Lampung menuju ke Bali. Dimana Pelayaran ini dimulai dari Pelabuhan Panjang,Lampung (1) - Pelabuhan Tanjung Priok, Jakarta (2) Pelabuhan Tanjung Emas, Semarang (3) - Pelabuhan Tanjung Perak, Surabaya (4) - Pelabuhan Benoa, Bali (5).

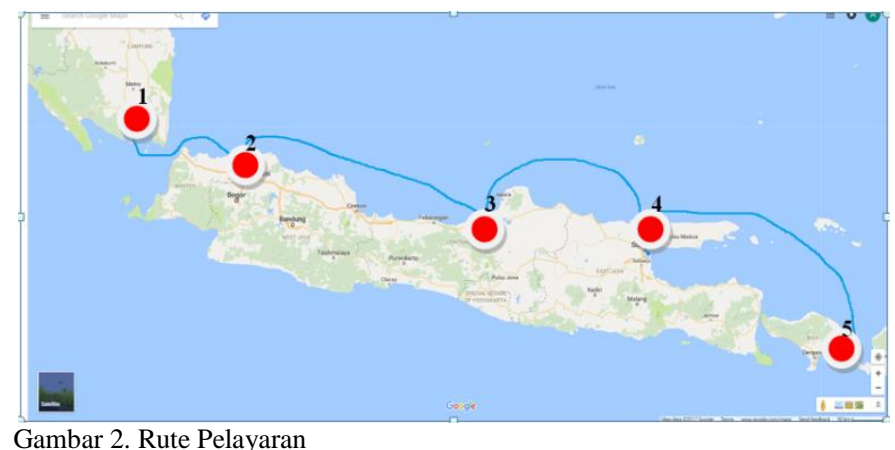

Gambar 2. Rute Pelayaran

\section{METODOLOGI PENELITIAN}

Berikut adalah diagram alir pengerjaan Studi yang ditunjukkan pada Gambar 3.

\section{ANALISIS TEKNIS}

\section{A. Payload}

Penentuan payload dari Truck Carrier Ro-Ro ini mengacu pada [5], dimana di dapatkan nilai payload awal sebesar 144 truk. Dari nilai tersebut dibuat beberapa variasi payload dengan range ke bawah dan ke atas, yaitu 106 truk, 131 truk, 164 truk, 180 truk dan 200 truk. Kemudian dibuat layout awal dari masing-masing variasi tersebut, sehingga di dapatkan ukuran utama awal dari tiap-tiap variasi. Setelah ukuran utama awal didapatkan, maka data ukuran awal dari tiap-tiap variasi tersebut di olah, sehingga didapatkan Biaya Kapital, Biaya Operasional, Biaya Pelayaran, Biaya Bongkar Muat,pendapatan, tarif, NPV, IRR, BEP dari tiap variasi payload. Data tersebut digunakan sebagai indikator untuk menentukan payload yang akan di gunakan pada studi ini.

Setelah didapatkan harga yang sudah dihitung pada Tabel 1 maka bisa di dapatkan nilai NPV, IRR dan BEP dari tiap-tiap variasi payload. Rekapitulasi perhitungan NPV, IRR dan BEP dapat dilihat pada Grafik 1,Grafik 2,Grafik 3 dan Grafik 4.

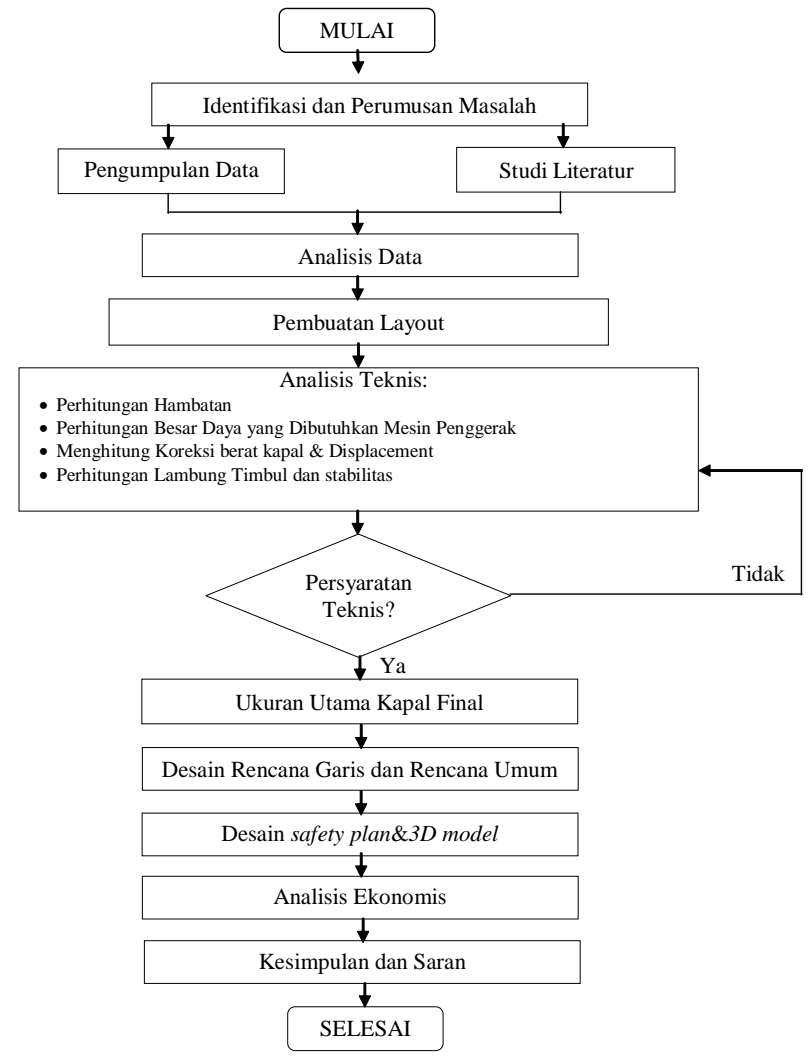

Gambar 3. Diagram Alir Pengerjaan Studi

Tabel 1

Rekapitulasi Perhitungan Biaya, Pendapatan dan Tarif Jenis Nominal

Biaya Kapital Rp 197.095.784.628.

Biaya Operasional Rp 93.868.901.724

Biaya Pelayaran Rp 43.367.406.754

Biaya Bongkar Muat $\quad$ Rp 474.500

Pendapatan

Tarif (per Nautical Mile)

Rp52.378.969.789

Rp 11.000

\section{B. Penentuan Ukuran Utama}

Setelah didapatkan nilai payload, maka dapat ditentukan ukuran utama yang digunakan adalah ukuran utama dari payload dengan jumlah 180 truk. Ukuran utama didapatkan dari jumlah truk yang disusun pada layout awal. layout awal dari payload 180 truk dapat dilihat pada Gambar. 4.

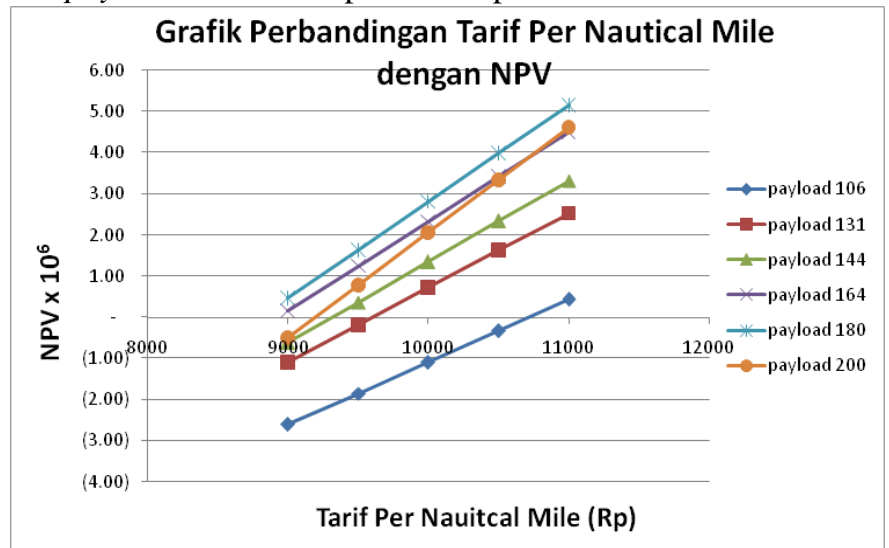

Grafik 1. Grafik Perbandingan Tarif Per Nautical Mile dengan NPV 


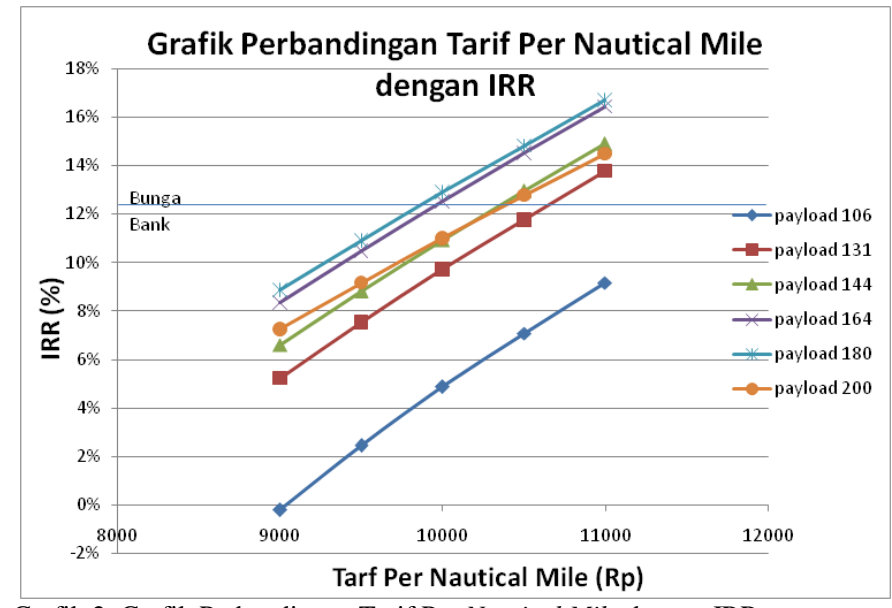

Grafik 2. Grafik Perbandingan Tarif Per Nautical Mile dengan IRR

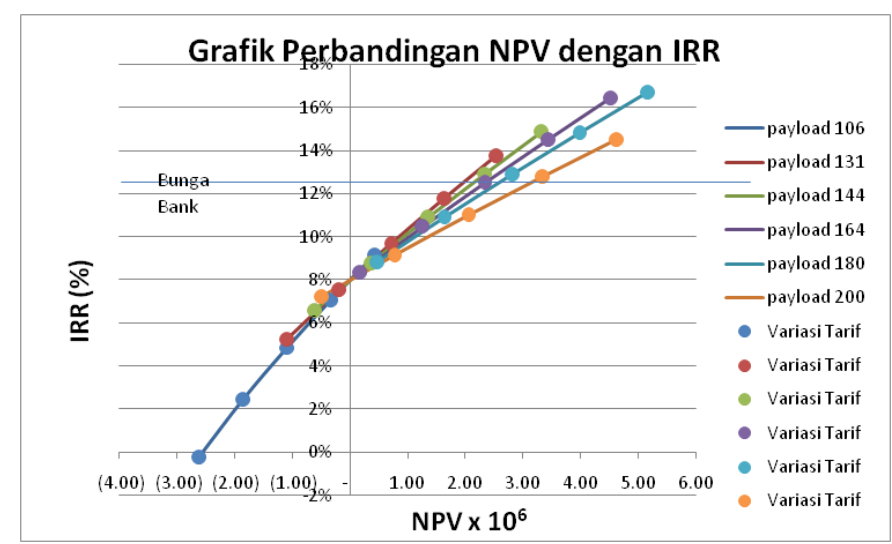

Grafik 3. Grafik Perbandingan NPV dengan IRR

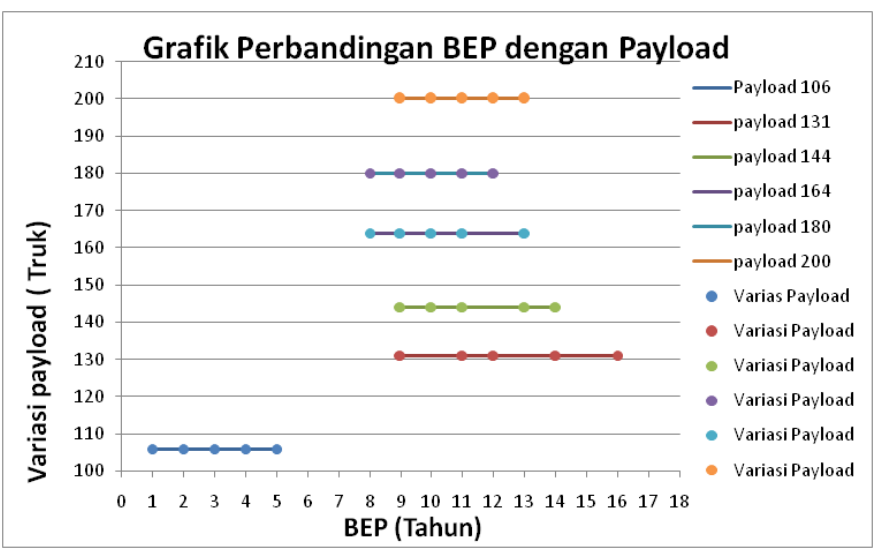

Grafik 4. Grafik Perbandingan BEP dengan Variasi Payload

\section{Perhitungan Awal}

Dari desain awal kemudian dihitung perhitunganperhitungan awal yang terdiri dari:
1) Koreksi ukuran Utama
2) Froude Number
3) Block Coefficient
4) Midship Coefficient
5) Prismatic Coefficient
6) Waterplane Coefficient
7) Longitudinal Centre of Buoyancy

8) Displacement

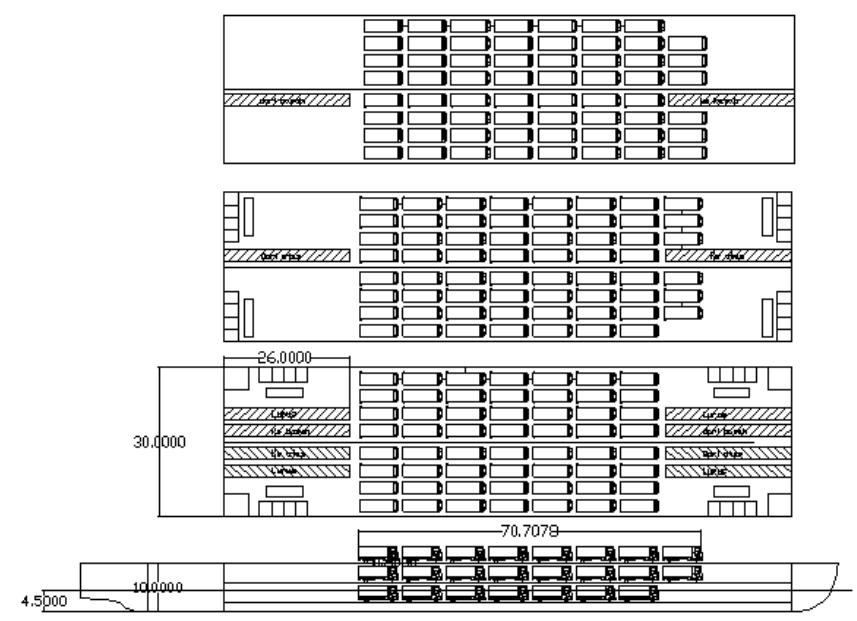

Gambar. 4. Desain Layout Awal

\section{Perhitungan Hambatan}

Pada Studi ini perhitungan hambatan Kapal menggunakan metode Holtrop dengan hasil akhir sebagai berikut:

$$
\mathrm{R}_{\mathrm{T}}=336.378 \mathrm{kN}
$$

Setelah nilai hambatan total didapatkan, maka dapat dilakukan perhitungan daya yang dibutuhkan untuk sistem propulsi kapal, yaitu sebesar 6562.194 kiloWatt $(\mathrm{kW})$.

\section{E. Lightweight Tonnage}

Lightweight Tonnage (LWT) merupakan berat kapal kosong, dimana terdiri dari berat baja dan konstruksi kapal, berat permesinan kapal dan berat peralatan kapal. Dari hasil perhitungan $L W T$ didapatkan $L W T$ kapal sebesar 8904.341 ton.

\section{F. Deadweight Tonnage}

Deadweight Tonnage (DWT) terdiri dari Payload (truk), berat bahan bakar, berat minyak pelumas, berat provision berat crew dan penumpang dan barang bawaanya, Dari hasil perhitungan DWT didapatkan DWT kapal sebesar 1881,1 ton.

\section{G. Freeboard}

Perhitungan freeboard mengacu pada International Convention of Load Lines (ICLL) tahun 1969. Freeboard Kapal sesungguhnya adalah sebesar $5 \mathrm{~m}$ dan freeboard minimum sebesar $1.640 \mathrm{~m}$.

\section{H. Stabilitas}

Kapal yang akan dibangun harus dapat dibuktikan secara teoritis bahwa kapal tersebut memenuhi standard keselamatan pelayaran Safety Of Life At Sea (SOLAS) atau International Maritime Organization (IMO). Perhitungan stabilitas dilakukan dengan bantuan software Maxsurf Stability Enterprise Education Version. Kriteria stabilitas yang 
digunakan dalam perhitungan software adalah IS Code 2008. Hasil perhitungan stabilitas dapat dilihat pada Tabel 2

Tabel 2

Kondisi Stabilitas Pada Tiap Loadcase

\begin{tabular}{|c|c|c|c|c|c|c|c|c|c|}
\hline Data & $\begin{array}{c}\text { Loadkase } \\
\text { I }\end{array}$ & $\begin{array}{l}\text { Londase } \\
\text { III }\end{array}$ & $\begin{array}{c}\text { Londase } \\
\text { III }\end{array}$ & $\begin{array}{l}\text { Loavase } \\
\mathbf{N}\end{array}$ & $\begin{array}{l}\text { Loaikase } \\
\mathbf{V}\end{array}$ & $\begin{array}{l}\text { Loadicase } \\
\text { VI }\end{array}$ & $\begin{array}{c}\text { Loaikase } \\
\text { VII }\end{array}$ & $\begin{array}{c}\text { Kriteria } \\
\text { IMO }\end{array}$ & Kondisi \\
\hline $\begin{array}{l}\sigma_{0-30} \\
\text { (mideg) }\end{array}$ & 909427 & 918237 & 712933 & 61.7733 & $153 \_063$ & 155542 & 1473957 & 23.1513 & Diterime \\
\hline $\begin{array}{l}\begin{array}{l}\overline{0}_{0-4 \sigma} \\
\text { (mdeg }\end{array} \\
\end{array}$ & 140354 & 1515622 & 1105201 & 94.7608 & 2463389 & 249.8149 & 234.9727 & \$51566 & Diterime \\
\hline $\begin{array}{l}30-10^{\circ} \\
(m \text { deg })\end{array}$ & 59.4927 & 59.7386 & 392088 & 32.9875 & 93.2759 & 94.2728 & 875769 & ?1.7189 & Diterime \\
\hline $\begin{array}{l}\mathrm{n}_{30^{\circ}} \\
\text { (mideg) }\end{array}$ & 6379 & 6.405 & 3958 & 3382 & 10.24 & 10337 & 93568 & 202 & Diterime \\
\hline$\theta_{\max }(\mathrm{dkg})$ & 49.1 & 49.1 & 327 & 309 & 564 & 564 & 509 & 725 & Diterime \\
\hline $\mathrm{GM}_{0}$ (m) & 11.784 & 11929 & 9.85 & 8.472 & 21.756 & 22255 & 21322 & 90.15 & Diterima \\
\hline
\end{tabular}

\section{Trim}

Trim adalah perbedaan tinggi sarat kapal antara sarat depan dan belakang. Sedangkan evenkeel merupakan kondisi di mana sarat belakang $\mathrm{Tb}$ dan sarat depan $\mathrm{Ta}$ adalah sama. Perhitungan trim dilakukan dengan menggunakan software Maxsurf Stability Enterprise Educational Version. Kriteria stabilitas yang digunakan mengacu pada SOLAS Reg. II/7, dimana kondisi trim maksimum yang diizinkan adalah sebesar 0,5\% Lpp. Hasil perhitungan trim dapat dilihat pada Tabel 3 Tabel 3

Kondisi Trim pada tiap Loadcase

\begin{tabular}{|c|c|c|c|c|}
\hline No & Kondisi & Batasan & Hasil & Status \\
\hline $\mathbf{1}$ & Loadcase 1 & $\mathbf{0 . 7 5 4}$ & $\mathbf{0 . 0 5 8}$ & Accepted \\
\hline $\mathbf{2}$ & Loadcase 2 & $\mathbf{0 . 7 5 4}$ & $\mathbf{0}$ & Accepted \\
\hline $\mathbf{3}$ & Loadcase 3 & $\mathbf{0 . 7 5 4}$ & $\mathbf{0 . 0 4 3}$ & Accepted \\
\hline $\mathbf{4}$ & Loadcase 4 & $\mathbf{0 . 7 5 4}$ & $\mathbf{0 . 3 0 4}$ & Accepted \\
\hline $\mathbf{5}$ & Loadcase 5 & $\mathbf{0 . 7 5 4}$ & $\mathbf{0 . 6 2 5}$ & Accepted \\
\hline $\mathbf{6}$ & Loadcase 6 & $\mathbf{0 . 7 5 4}$ & $\mathbf{0 . 0 5 4}$ & Accepted \\
\hline $\mathbf{7}$ & Loadcase 7 & $\mathbf{0 . 7 5 4}$ & $\mathbf{0 . 0 5 1}$ & Accepted \\
\hline
\end{tabular}

\section{J. Lines Plan dan General Arrangement}

Rencana garis merupakan gambaran bentuk lambung kapal yang diproyeksikan menjadi tiga sudut pandang yaitu sudut pandang depan, samping dan atas. Pembuatan rencana garis menggunakan bantuan software Maxusrf Modeler Advanced Educational Version dan Autodesk AutoCAD Student Version. Langkah awal adalah pembuatan model menggunakan bantuan software Maxsurf. Model di dapatkan dengan bantuan sample design. Kemudian dilakukan perubahan pada beberapa elemen antara lain ukuran utama, grid spacing dan zero-point sesuai dengan kapal yang akan didesain. Control Point mempengaruhi bentuk badan kapal. Displacement dapat diubah dengan mengubah Control Point pada bagian bawah garis air kapal.. Gambar Lines Plan dapat dilihat pada Gambar 5.

Rencana umum merupakan perencanaan ruangan di dalam kapal yang dibutuhkan sesuai dengan fungsi dan perlengkapan kapal. Pembuatan Rencana Umum dilakukan dengan bantuan software Autodesk AutoCAD Student Version. Gambar Rencana Umum dapat dilihat pada Gambar 6.

\section{K. Safety Plan}

Safety Plan merupakan perencanaan keselamatan penumpang pada kapal. Desain Safety Plan didesain berdasarkan aturan SOLAS. Pembuatan Safety Plan dilakukan dengan bantuan software Autodesk AutoCAD Student Version. Gambar Safety Plan dapat dilihat pada Gambar 9.

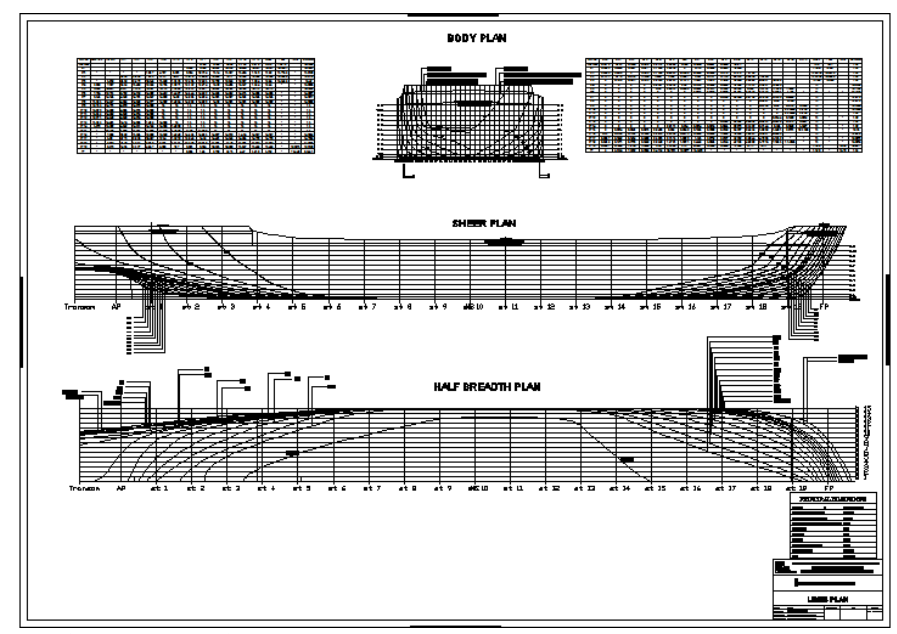

Gambar 5. Lines Plan

\section{Pemodelan 3 Dimensi Kapal}

Pemodelan 3 Dimensi (3D) kapal ini harus sesuai dengan ukuran utama kapal dengan bentuk lambung yang proporsional terhadap desain lambung kapal yang di bantu dengan software Maxsurf. Pemodelan 3D dibantu dengan software Sketch Up. Hasil pemodelan 3D Kapal dapat dilihat pada Gambar 7, Gambar 8, Gambar 10 dan Gambar 11.

\section{ANALISIS EKONOMIS}

\section{A. Biaya Pembangunan}

Perhitungan (estimasi) biaya pembangunan kapal mengacu pada pedoman perkiraan biaya dari Direktorat Pengolahan Pertamina. Sehingga didapat biaya pembangunan kapal sebesar Rp 162.302.693.000 (Seratus Enam Puluh Dua Miliar Tiga Ratus Dua Juta Enam Ratus Sembilan Puluh Tiga Ribu Rupiah).

\section{B. Break Event Point (BEP)}

Perhitungan BEP didapatkan dari hasil perhitungan Biaya Pembangunan, Biaya Operasional, Biaya Pelayaran, Biaya Bongkar Muat kemudian dibandingkan dengan Pendapatan per trip sesuai dengan tarif per Nautical Mile yang sudah ditentukan. Pendapatan dan tarif dapat dilihat pada Tabel 1 Sehingga didapatkan BEP pada tahun ke 8 (Delapan) dengan estimasi keuntungan bersih sebesar Rp.80.468.618.251 (Delapan Puluh Miliar Empat Ratus Enam Puluh Delapan Juta Enam Ratus Delapan Belas Ribu Dua Ratus Lima Puluh 1 Rupiah).

\section{KESIMPULAN}

Berdasarkan uraian dari Studi ini, dapat diambil kesimpulan sebagai berikut:

1) Payload Kapal didapatkan sebesar 180 truk dengan ukuran utama Lpp: 145 m; B: 30 m; T: 6 m; H: 11 m.

2) Desain Rencana Garis telah dibuat.

3) Desain Rencana Umum telah dibuat. 
4) Desain Safety Plan dan Desain 3D telah dibuat.

5) Perhitungan ekonomis telah dilakukan dengan estimasi biaya investasi sebesar Rp 517.302.434.648 (Lima Ratus Tujuh Belas Miliar Tiga Ratus Dua Juta Empat Ratus Tiga Puluh Empat Ribu Enam Ratus Empat Puluh Delapan Rupiah) dengan estimasi keuntungan bersih pertahun adalah Rp 52.378.969.789 (Lima Puluh Dua Miliar Tiga Ratus Tujuh Puluh Delapan Juta Sembilan Ratus Enam Puluh Sembilan Ribu Tujuh Ratus Delapan Puluh Sembilan Rupiah).

\section{LAMPIRAN}

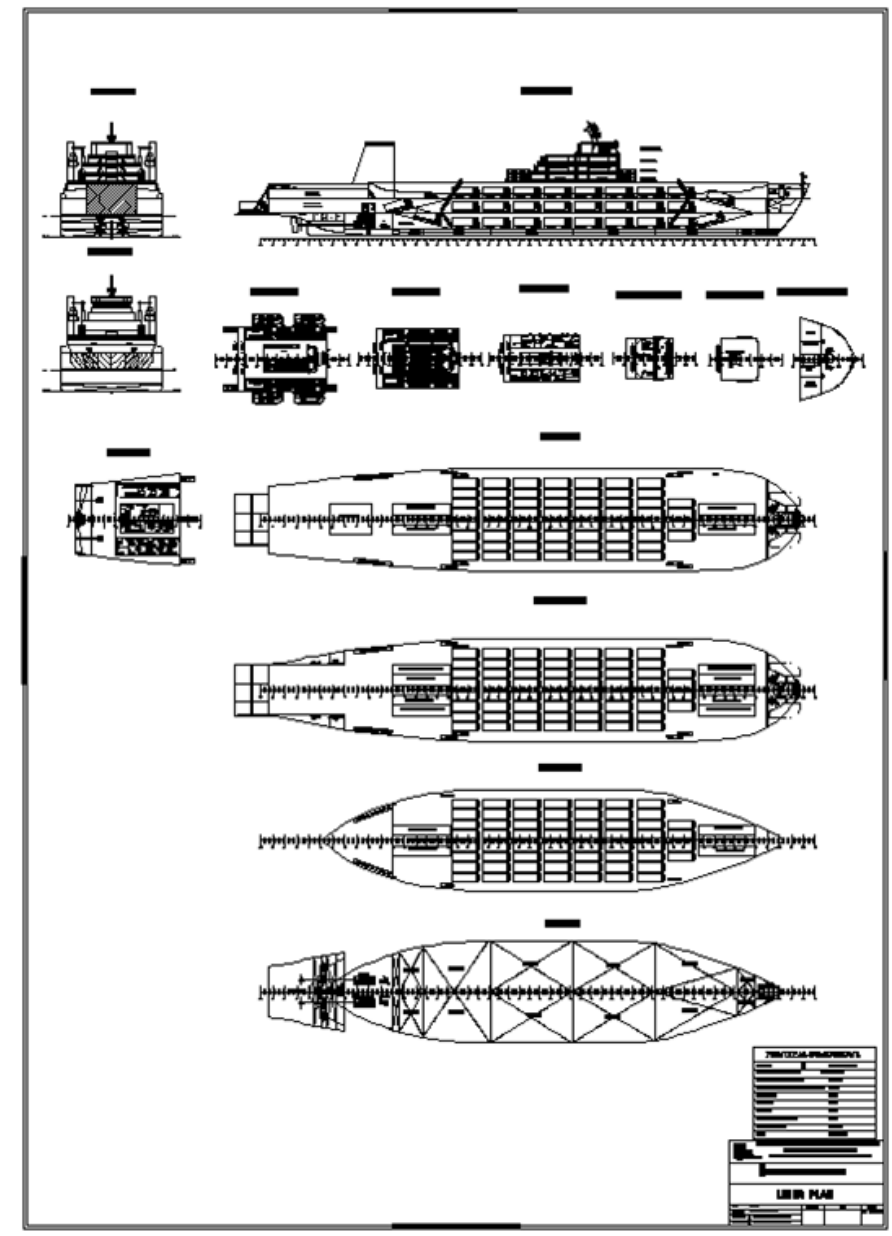

Gambar 6. Rencana Umum

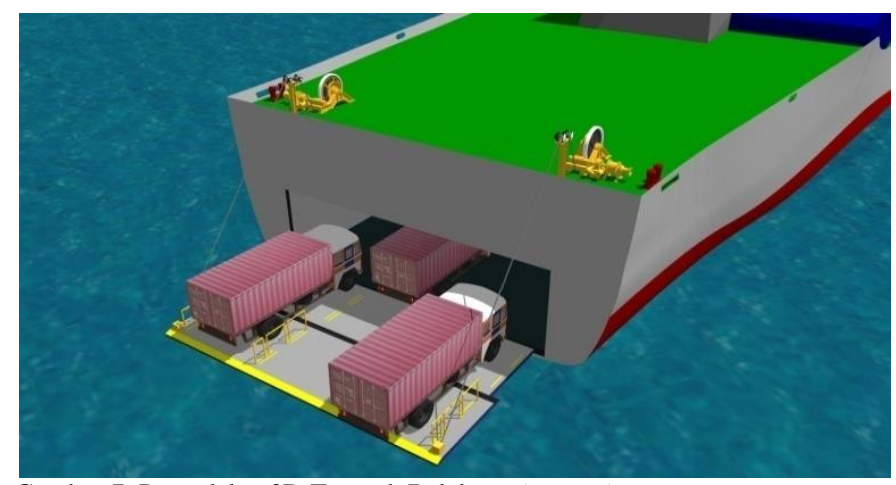

Gambar 7. Pemodelan 3D Tampak Belakang isometric.

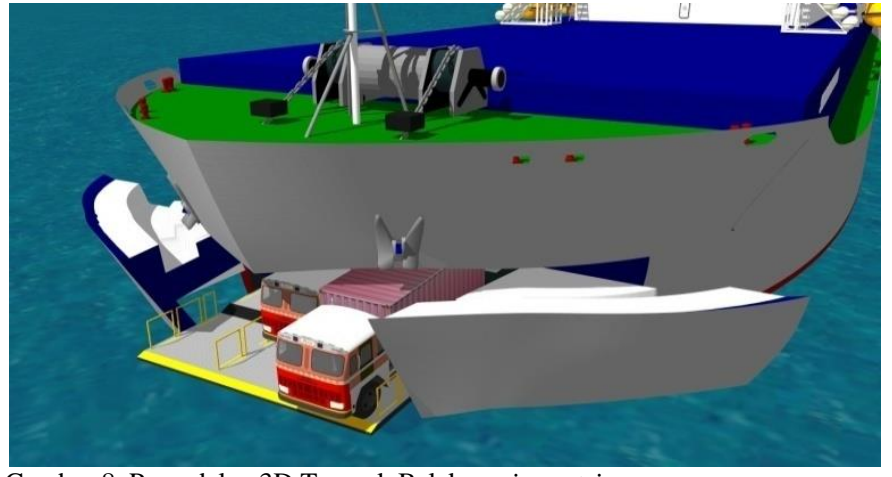

Gambar 8. Pemodelan 3D Tampak Belakang isometric.

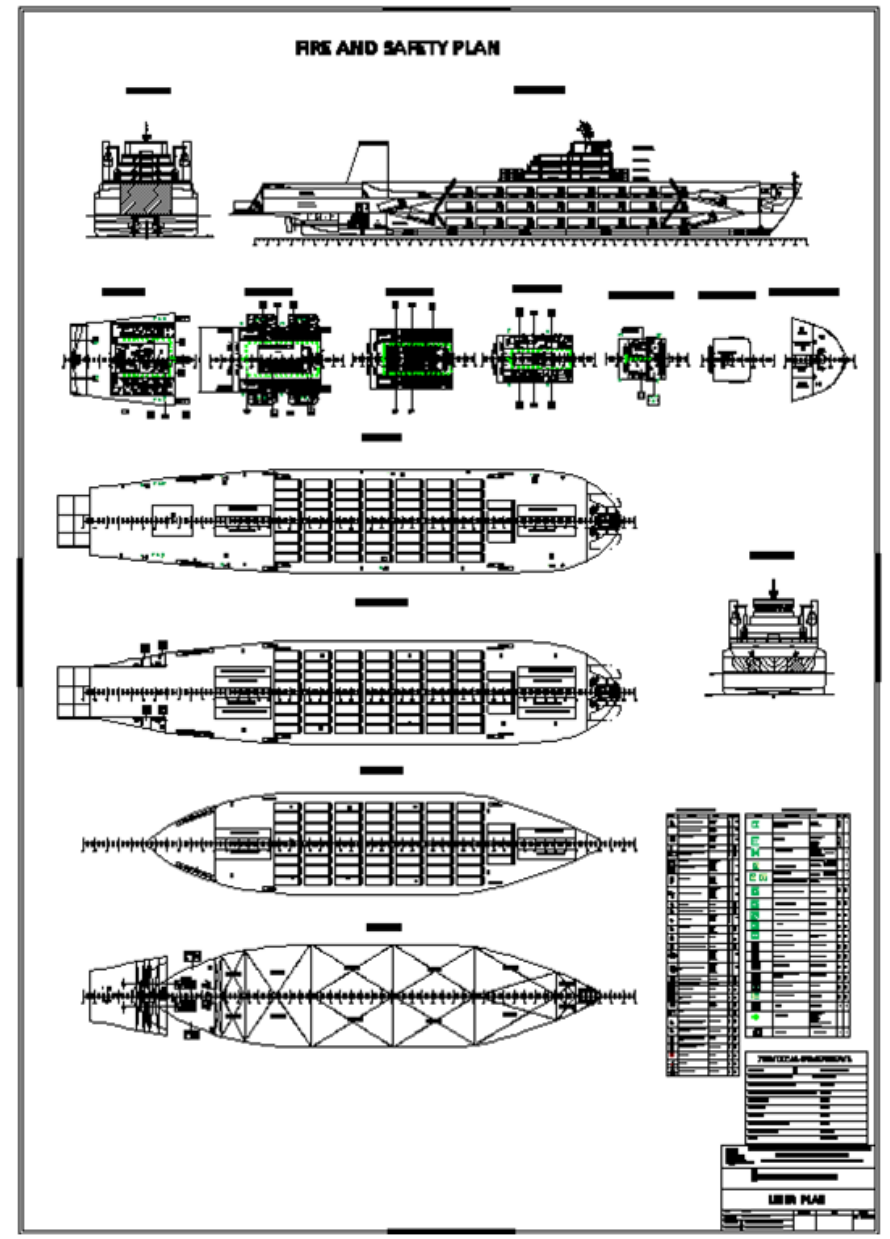

Gambar 9. Safety Plan

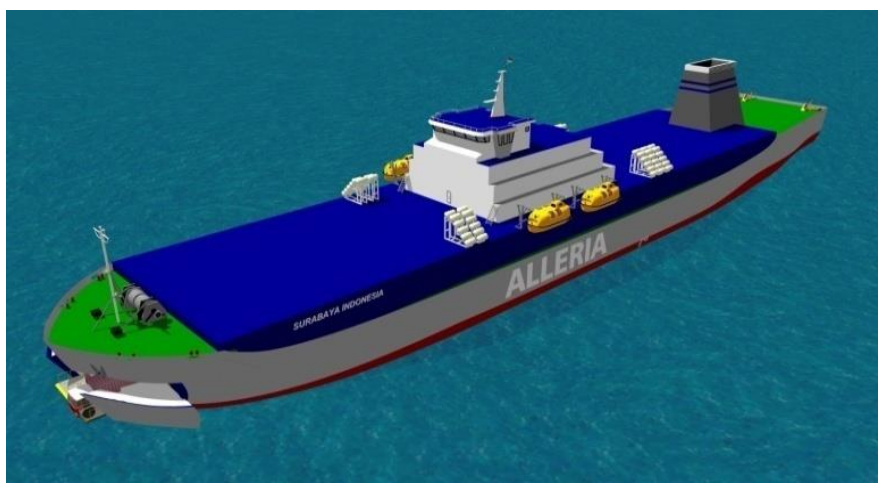

Gambar 10. Pemodelan 3D Tampak Atas Depan isometric. 


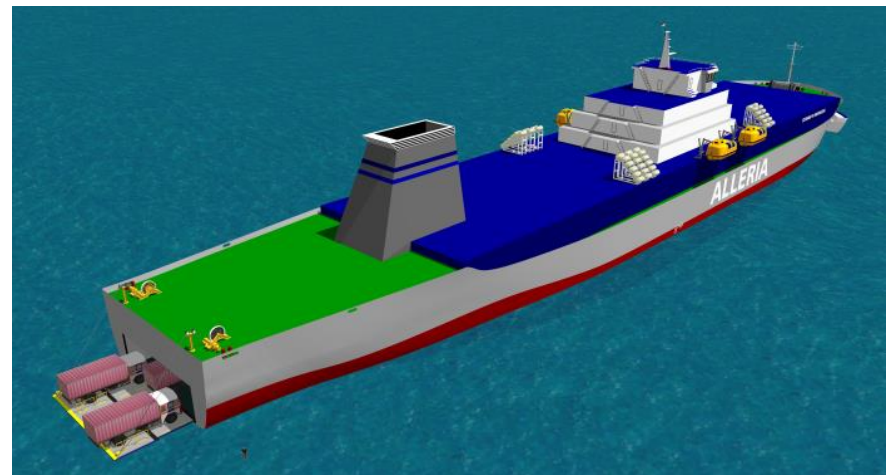

Gambar 11. Pemodelan 3D Tampak Atas Belakang isometric.

\section{DAFTAR PUSTAKA}

[1] "www.kompasiana.com.," kompasiana, 2016

[2] "kompas.com," 2016. [Online]. Available: http://bisniskeuangan.kompas.com/read/2016/11/20/175331126/truk .banjiri.jalan.raya.kapal.roro.akan.jadi.alat.angkut.dari.lampung.ke.b ali.

[3] "id.wikipedia.org," $2016 . \quad$ [Online]. Available: https://id.wikipedia.org/wiki/Kapal_Ro-Ro.

[4] "id.wikipedia.org," $2016 . \quad$ [Online]. Available: https://id.wikipedia.org/wiki/Truk.

[5] F. C. Rahmita, "Studi Jurusan Teknik Perkapalan. Desain Inovasi Kapal Truck Carrier Rute Surabaya-Jakarta Untuk Mengurangi Kemactean Jalan Pantura Jawa,” ITS, 2015. 